\title{
A Review of William Blake's "Songs of Innocence and Songs of Experience" in Persian Translation
}

\author{
Maryam Pakzadian \\ University of Isfahan, Iran \\ Ahmad Moinzadeh \\ University of Isfahan, Iran
}

\begin{abstract}
All who research and study about William Blake's works more or less know about the nature of his most salient work, Songs of Experience and Songs of Innocence . The Songs of Innocence tries to reflect child's innocence and ignorance of worldliness. They focus on childhood happiness and improvisation. Those who work in the field of literary translation are aware of those limitations and bounds which a translator may face with, (sociolinguistic matters, cultural bounds, discourse issues...) none of which will lead us toward rejecting the essence of translator and translation. As Robert Frost says: "in a literary translation the only thing we miss is the poem itself" and even the best translators can not be aware of the exact philosophy of the poem, because it's just in the mind of poet and inaccessible to others. But all in all we translate poems and we try to share experiences. This paper is the result of years of reading and introspecting in to William Blake's Song of Experience and of Innocence. While translating the collection to Persian the researcher encounters with number of questions, which she tries to present answers for them. So a sort of comparative, contrastive analysis between original English version and its Persian translation appeared. In this paper the writer chose 3 sample poems and their translations in order to discuss translation issues she encountered with reading and translating Blake. The results showed key factors in translating Blake are: symbolism, original spelling and punctuation, knowing about author's biography.
\end{abstract}

Index Terms-William Blake, Songs of Experience and of Innocence, translation, literary, Persian, English

\section{INTRODUCTION}

It goes without saying that translation has always been important in human communication. Translators try to transfer source text to target text, therefore transferring new ideas, meanings, and beliefs from one language to the other. At times they act like a bridge connecting two different cultures. By translation, new thoughts, philosophies and points of views are entered into different languages. In case of literary translation, as people are more interested in reading novels, poems and literary works, the need for good translation is more felt. You don't have a limited range of audience but a large number of them, they may not be aware of characteristics of original texts and poems but to large extent they differentiate good translation with weak one. Maybe ordinary readers with no educational background in English and Persian literature can not understand details but among your readers there are some careful readers who always read to highlight the gaps, who always compare the text and translation in a systematic manner. Even if it's not the case you owe the writer. You are responsible for all philosophies, ideas and point of views that you transfer rightly or wrongly. In case of William Blake's works your responsibility is doubled, its lofty mysticism, reach symbolism and philosophical content should be properly transferred. Of course you can not make a one to one parallel between original text and its Persian translation but you should try your best to keep salient characteristics of the text. Unfortunately most of papers and researches about Blake's poetry are about its English version not about process of its translation to other languages or comparing its translations with original text. Subtlety of its concepts, its big ties with Bible and Milton's Jerusalem, its spiritual visions, its ties with the writers own experiences throughout his life all in all make the text difficult to be translated. Actually Songs of Innocence and of Experience never been translated on its own in to Persian. In this paper the writer tries to investigate some discrepancies of original text with its Persian translation, the writer translates while knowing about some inevitable gaps from original text ,trying to reduce their effects on transferring content and structure. Three issues will be discussed here, in process of comparing original text with its translation: mysticism and symbolism, spelling and punctuation, writer's biography. I chose three sample poems and their translation for discussing each issue. Respectively: AH, SUNFLOWER from songs of experience, INTRODUCTION from songs of innocence and finally TO TIRZAH from Songs of Experience.

\section{A Short Glance}


William Blake (November 28, 1757-August 12, 1827) was an English poet, painter, and printmaker. William Blake was one of England's greatest poets. He combined both a lofty mysticism and an uncompromising awareness of the harsh realities of life. As a young boy he had a most revealing vision of seeing angels in the trees. These mystical visions returned throughout his life, leaving a profound mark on his poetry and outlook. William Blake was also particularly sensitive to cruelty. His heart wept at the site of man's inhumanity to other men and children. In many ways he was also of radical temperament, rebelling against the prevailing orthodoxy of the day (Pettinger, 2012).

Many of Blake's best poems are found in two collections: Songs of Innocence (1789) to which was added, in 1794, the Songs of Experience (unlike the earlier work, never published on its own). The complete 1794 collection was called Songs of Innocence and Experience Showing the Two Contrary States of the Human Soul. Broadly speaking the collections look at human nature and society in optimistic and pessimistic terms, respectively and Blake thinks that you need both sides to see the whole truth (Moore, 2004).

Blake as a poet and artist presented his deep spiritual meanings in Songs of Innocence and of Experience and it will be a fault not to consider the role of his engravings in presenting deep meanings. The 'experience' is often depicted as dark forest in which mankind finds itself as lonely and lost. And The Paradise Bird is the symbol of freedom and innocence in Blake's poetry. Both of these symbols are present in his engravings.

\section{A. William Blake's Symbolism}

One of the very important and known features of Blake's poetry is the use of symbols. In all of his poems there is the footprint of symbolism besides surface meaning. Though many believe that Blake's poems are written in a simple language, no one can deny the presence of deep meaning. However in order to catch deep meaning you should have knowledge about the use of symbols in Blake's poetry which have been classified into innocence symbols, energy symbols, sexual symbols, corruption symbols, oppression symbols and so on.

Blake is one of the known figures in Romantic Period (1785-1830). Romantic poets had idealistic view about human's sprit which will be spoiled with worldliness. One of very important themes in that time was revolution which means replacing industrial with natural life style. Poets at that time were playing the role of profits who warned people against such happening. Many of the images used by Blake have their roots in bible. In "The Lamb" and "The Tyger" Blake tried to draw a picture of God's creation of meek and fierce creatures together. Blake believed in Transcendentalism which means God is present in all creatures. Romantic poets were considered as profit poets and their poems were considered as their prophecy.

In case of symbolism we face with some Qs:

-How to translate symbols?

-Are we allowed to break symbols or not?

-Understanding of intended meaning: possible or impossible?

-Do we need to specify specific audience or all are capable of understanding target meaning?

-Symbols inserted in poems just compatible with English culture and context or they have equivalent semantic property in Persian?

-Is the intended meaning beyond this symbol understandable without breaking symbol?

-Do we have sun flowers as potent symbols for desire in Persian? Or we should replace it with another symbol with the same meaning behind?

-Is it possible to leave everyone having his own interpretation of this symbol?

-Is keeping the symbol in original form one aspect of being loyal to writer and text?

\section{Sample: AH, SUNFLOWER from songs of experience:}

"AH, SUNFLOWER

Ah, sunflower, weary of time,

Who countest the steps of the sun;

Seeking after that sweet golden clime

Where the traveller's journey is done;

Where the Youth pined away with desire,

And the pale virgin shrouded in snow,

Arise from their graves, and aspire

Where my Sunflower wishes to go! "

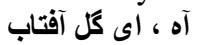

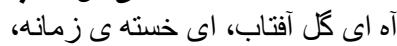

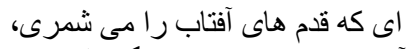

و در جستجوى آن فريبا ديارى كه به رئ رنى طلاست،

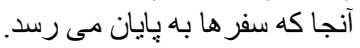

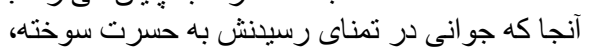

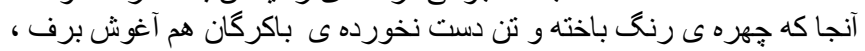

كفن يوش ترش

از آرامخاه هايشان بر مى خيز بـند،

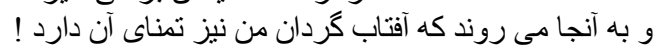


The sunflower is a symbol for desire. Based on Greek legend sunflower there was a woman who "pined away with desire after the Sun God" and after that she became a sunflower who moves based on the movements of the sun.

This poem talks about suppressed desires. As sunflower cannot reach sun and fulfill her desire the virgin cannot fulfill her desires because of society and its limitations. The Virgin is "pale" and "shrouded" and this depicts death and a half lived life. Her desires are buried now so the death will happen.

As I searched a lot in Persian literature there is no consensus about having sunflower the symbol for a desire which is pined away or not. They could not mention another symbol for this concept in Persian. But most of the teachers who were educated in Persian literature said sunflower can be a symbol for: worship, being proud, worshiping sun, sun, warmness, etc .some of them indirectly pointed at desire but it was not a know symbol for desire among Persian native speakers. Even in case of English native speakers it's not common as a symbol for desire, just those who have academic background in English literature or those who are familiar with Greek literature can fully realize the concept of this symbol in aforementioned poem. With replacing the symbol with another known symbol for desire in Persian literature not only we won't be loyal translators but also we miss Blake's philosophy behind this symbol even if there is a known single parallel symbol in Persian for that. So the best way in my sight is leaving readers to have their own interpretations. They should study about Blake's poems in Spark Notes or many other sites, they should care for their summary, analysis, key points... if they wish for full understanding. For those who don't know English unfortunately they will miss most of the philosophy and mystic mood of his poems, with knowing the fact that Blake is a mystic who writes with complicated symbols which seem simple at surface level. So these readers just can enjoy Persian translation which is unable to reach them to deep content. In my view Blake's readers need to be far beyond surface with great knowledge of literature, philosophy, Bible, Greek legends and salient features of Blake's works.

\section{B. Blake's Original Spelling and Punctuation Marks}

- Sometimes it's really hard to know how you should transfer punctuation marks from English text to its parallel translation in Persian. What should we do?

- Are they just the matter of writing and editing style or they have intended meaning behind (they are important in comprehension process)?

- How we can insert punctuations in parallel translation, after the exact word in original text or you can modify its place according to Persian and its specific writing and editing style?

\section{Sample: TO TIRZAH, from Songs of Experience}

\section{TO TIRZAH}

"Whate'er is born of mortal birth

Must be consumed with the earth,

To rise from generation free:

Then what have I to do with thee?

The sexes sprung from shame and pride,

Blowed in the morn, in evening died;

But mercy changed death into sleep;

The sexes rose to work and weep.

Thou, mother of my mortal part,

With cruelty didst mould my heart,

And with false self-deceiving tears

Didst blind my nostrils, eyes, and ears,

Didst close my tongue in senseless clay,

And me to mortal life betray.

The death of Jesus set me free:

Then what have I to do with thee?"

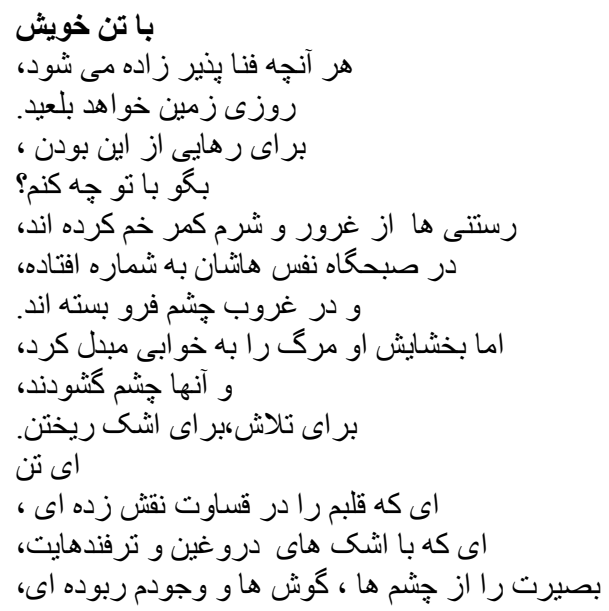




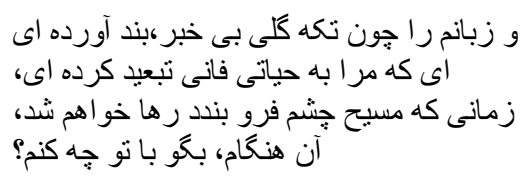

If you take look at the original English text and compare it with Persian translation in most of the cases I changed the punctuation marks, I didn't want to transfer them to Persian translation although I knew they definitely bear special meanings, and Blake didn't use them without intended meaning behind. But with knowing the fact that Persian and English have different use of punctuation marks in some cases and what fits in English version does not fit in Persian text necessarily I chose some of them, trying to keep them in most of the cases. Although it's inevitable to move from one language to another without getting prepared for necessary changes in structure and form. Different languages use different forms and even punctuation marks to point at same meaning. I put the punctuation marks according to Persian writing and editing style.

\section{Knowing about Poet's Biography: A Key Factor}

According to Romantic criticism in order to have better criticism and also interpretation from the text (whether a prose or poem) its necessary to know about the biography of its writer or poet because individual's expression of reality far from established rules and conventions are essence of romantic works, although as Eliot says: its not always the case that all the literary works are based on real experiences of their owners. But in William Blake's poems sometimes without knowing about his life and career proper understanding never happens. In the poetry of Blake the influence of society on human life is evident. His aversion to contemporary English society found expression in 'The Songs of Innocence and Experience'. Also reflects the radical political ideas he had. The poverty he witnessed around him led to the outburst against the societal setup he lived in. William Blake poetry was also deeply influenced by the French Revolution. His preoccupation with the evil and good and his deep rooted religious and philosophical thoughts were depicted in his poetry all along. Ironical as it seems, Blake's contemporaries and critics did not pay much attention to his poetry in his lifetime and they preferred to admire his engravings. It was the publication of Alexander Gilchrist's biography in 1863 that improved his critical fortune.

William Blake embarked on the Poetic scene when the society was undergoing massive changes and being born in the era of transition helped him to pave the way for the Romantic poets. He treated subjects like politics, art, morality and religion with a strange concoction of mythological interpretations. In doing so he broke away from the boundaries of rationalism. William Blake quotes found in his famous work Songs of Innocence and of Experience corroborate this. He justified his art once by saying "What is Grand is necessarily obscure to Weak men. That which can be made Explicit to the Idiot is not worth my care".

\section{Sample: INTRODUCTION from songs of innocence: \\ INTRODUCTION}

"Piping down the valleys wild,

Piping songs of pleasant glee,

On a cloud I saw a child,

And he laughing said to me:

'Pipe a song about a Lamb!'

So I piped with merry cheer.

'Piper, pipe that song again.'

So I piped: he wept to hear.

'Drop thy pipe, thy happy pipe;

Sing thy songs of happy cheer!'

So I sung the same again,

While he wept with joy to hear.

'Piper, sit thee down and write

In a book, that all may read.'

So he vanished from my sight;

And I plucked a hollow reed,

And I made a rural pen,

And I stained the water clear,

And I wrote my happy songs

Every child may joy to hear."

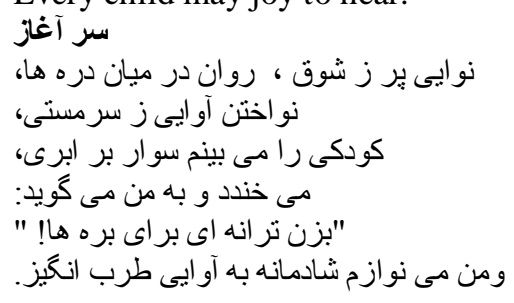




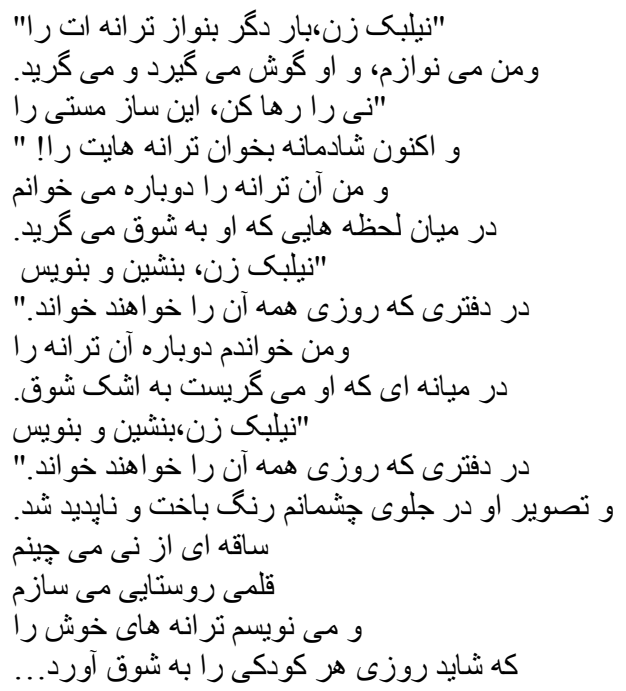

In many of Blake's poems he has a shadow, being a forebiding sense of loss of innocence to come. In this instance, the shadow is when the piper makes a rural pen and writes his happy songs for children who may feel joy after hearing them. The piper represents experience, and the child on a cloud of course, is innocence. This child is eager to hear the experienced piper's tunes and songs, and so his fall of innocence is inevitable. So without knowing that William Blake had a younger brother, Robert, who died in childhood because of consumption it's actually hard to comprehend and translate some of his poems in his collections. He was Robert, Blake's dead brother who was "clapping its hands for joy on the ceiling." Blake believed that Robert's sprit never left him and visited him continuously. He even claimed that it was Robert who taught him the special method of printing that Blake used them in Songs of Innocence and Songs of Experience in his dreams.

As the translator when I read the original poems for the first time I understood nothing! I got the point after reading the first poem of Innocence songs, which is Introduction. When I asked my professor who is this boy on the cloud, she said you didn't read enough about Blake's life?! As I left for library and I studied different books and visited different pages on the net I came to know who this boy is! So even me as a person educated in English literature needed to study about Blake's life in order to get the gist let alone readers who don't know anything about English literature and a romantic poet like Blake. So if you want to enjoy the translation which is a poem itself and enjoy just the rhythm forgetting all about Blake you can just go through pages without introspecting in them. But if you read for Blake, read all and at last Persian translation.

\section{CONCLUSION}

While reading and translating Blake I felt a joy never experienced before in reading other religious books. It had a great impact on me. Blake was the one who wept for the sake of humanity, who was against inhumanity to children and other people. He never gets hopeless even in Songs of Experience in which he takes a pessimistic view; he always can see and feel the presence of God. God is who sits beside you and cries for you when you are like a lamb afraid of wolves. His unique symbols and mysticism throughout "Songs of Innocence and of Experience" made me think of Sohrab Sepehri and his deep philosophy and even Molana. Those who want to think about creation, God and the philosophy of life can enjoy Blake's poems exactly like in Sohrab Sepehri's poems, even more deeply. I know inevitably I missed some parts in the process of translating from punctuation to structure and form or even the concept which is intended by the writer himself. But I'm sure I reached at the point he wanted me to reach at, I know no one can be sure he got the same ideas that the writer had while writing a work but I really was swept up and actually away after reading this work and I think this is the ultimate goal of each writer. For translating each poem I studied the English summary, notes, analysis, and writer's notes and of course I used my talent in writing not as a poet but at least a versifier! I think Blake is not that mad man who others blame for different psychic problems but the one who got the gist of life, who came to know the philosophy of being and God , and everyone after finding about such subtlety might be mad. If you never felt for reading Bible or religious books I recommend you reading Blake, which is the gist of all.

\section{REFERENCES}

[1] Blake, W. (1967). Songs of innocence and of experience, reproduction of Blake's original illustrated book, Ed. And commentary by G Keynes, Rupert Hart-Davis Ltd., London, In association with The Trianon Press, Paris.

[2] Dorfman, D. (1969). Blake in the nineteenth century: His reputation as a poet from Gilchrist to Yeats. Yale University Press, New Haven.

[3] Hunt, R. (1809). 'Mr. Blake's Exhibition', excerpt from article published in the Examiner, London, in H Adams (ed.), Critical Essays on William Blake, G.K. Hall \& Co., Boston, 1991, pp. 22-23.

[4] Lindsay, D. (1989). Blake: Songs of innocence and experience. Macmillan, Basingstoke. 
[5] Malcolmson, A (ed.) (1967). William Blake: an introduction. Constable Young Books Ltd, London.

[6] Moore, A. (2004). Poems by William Blake - study guide. Retrieved Dec 04, 2009 from http://www.eriding.net/amoore/poetry/blake.htm.

[7] Palmer, S, letter to A Gilchrist, in H Adams (ed.) (1991). Critical Essays on William Blake. G.K. Hall \& Co., Boston, pp. 33 -36.

[8] Pettinger, T. (2006). Biography of William Blake. Oxford, UK www.biographyonline.net, Page updated 23rd Jan, 2012.

Maryam Pakzadian (First author) has an MA in ' Teaching English as a foreign Language' from University of Isfahan and she has got her BA in 'English Literature' from University of Isfahan. She has been involved in research in English Literature, Literary Translation, psycholinguistics, and Computer Assisted Language Learning. He has presented different lectures on Literary Translation, Teaching Translation and CALL.

Maryam is currently working on 'Persian Translation of William Blake's Songs of Innocence and Songs of Experience' and 'A New Approach to teaching Literature in Iranian Universities'.

Ahmad Moinzadeh works in the English department, University of Isfahan, Where he is assistant Professor of Applied Linguistics. He has a PhD in ' Applied Linguistics' from University of Ottawa. 